\title{
Students' Experiences, Reactions and Opinions on Bullying at Esperanza National High School, Esperanza, Sultan Kudarat, Region XII, Philippines \\ DOI: https://doi.org/10.47175/rielsj.v2i2.257
}

\section{| Rodalyn O. Lapada ${ }^{1}$ | Elmar S. Lapada² |}

${ }^{1}$ Teacher III, Esperanza

National High School, Mabolo

St., Poblacion, Esperanza,

Sultan Kudarat, Region XII, Philippines

${ }^{2}$ Teacher I,Esperanza National High School, Mabolo St., Poblacion, Esperanza, Sultan Kudarat, Region XII, Philippines samsudinabdullah42@yahoo.com

\begin{abstract}
This study was conducted to determine students' experiences, reactions and opinions on bullying. It used a descriptive research design wherein students' experiences, reactions and opinions were gathered through survey questionnaires. Purposive sampling technique was employed using snowball sampling technique. Online survey questionnaire was sent to the selected students via messenger. These students forwarded the online survey questionnaire to those students who they thought potential respondents of the study via messenger too. Finding revealed that Esperanza National High School has maintained a healthy school environment suited to the different types of learners since the bullying was less evident in the school. Occasional occurrence of bullying in the school prompted the students to rarely report the incidence to the concerned people. Students very seldom experienced the bullying from the people they frequently engaged and communicated. They normally responded to the minor incidence of bullying they experienced from the school or at home. They believed that bullying has a less extent of effect on their personal development. It is, indeed, recommended that Esperanza National High School should sustain building a positive school environment and should maintain the zero tolerance of any bullying incidence in the school.

KEYWORDS

bullying; student; high school; reaction; opinion
\end{abstract}

\section{INTRODUCTION}

Bullying exists in all communities since long time ago. It is considered as a common form of violence in schools. Various studies indicated that bullying makes schools to be unsafe places for students as it contributes in the belief that some schools are no longer safe for children. Bullying is deemed a very serious problem in academic setting in all parts of the world. It has a negative impact on academic performance and behaviors of students (AlRaqqad et al., 2017).

Despite of the strong and firm stand of any learning institution against any form of violence in school, bullying still happens. Bullying is a repetition of irritable conduct displayed by someone using force or coercion to disturb others, particularly when this behavior is routinely manifested and involves one-sided influence. It includes verbal harassment, physical assault or blackmail and may be directed repeatedly towards particular victims, perhaps on grounds of race, religion, gender, sexuality, or ability. Li (2015) stated that bullying can affect students - those who are bullied, those who bully, and those who witness bullying. Bullying is linked to many negative outcomes including impacts on mental health, substance use, inferiority complex, and sometimes suicide. 
Maliki et al. (2009) stated that lesser quantities of bullying incidence are found in schools with a positive school environment. Classroom climate would be less positive with bullies and victims. Depression, social isolation, mental health problems, anxiety, increased feelings of sadness and loneliness, change in sleep and eating patterns, loss of interest in activities and lower academic performance are some identified effects of bullying. These issues may persist into adulthood, health complaints and decreased academic performance and school participation. Students who are part of bullying incident are more likely to miss, skip, or drop out of school. A very small number of bullied children might retaliate through extremely violent measures. Forsberg (2016) emphasized that a student is being bullied or victimized when he is exposed, repeatedly and over time, to negative actions on the part of one or more students and the student who is exposed to negative actions has difficulty defending himself against bullies. This simply means that if a student is bullied, either he or she will become defenseless or he is triggered to bully other students.

Further, bullying is largely connected to the school context. Learning institutions have to be goal oriented in their child protection policy, prevent bullying from occurring, as well as put together yearly a comprehensive plan regarding their arrangements to counteract bullying or any form of violence. Although bullying is highly prohibited in schools, many incidents of this detrimental behavior can be observed. Teachers and staff should be subscribed with responsibilities to counteract such incidents.

Any form of bullying is unacceptable in the schools and will not be tolerated. Thus, this research generally aims to determine students' experiences, reactions and opinions on bullying as a basis for developing school-based child protection policy which hopes to end any act of exploitation, violence, discrimination, bullying and other forms of child abuse in the school. It will be conducted to protect the rights of all students by offering them an opportunity to learn, boost their full potentials and ensure that they can work in an environment without fear.

\section{Statement of the Problem}

This research aimed to determine the experiences, reactions and opinions of students on bullying at Esperanza National High School for the School Year 2020 - 2021.

Specifically, this study sought answers to the following questions:

1. To what extent are the experiences of the students on the following types of bullying at school and at home:

1.1 Physical Bullying;

1.2 Verbal Bullying;

1.3 Relational Bullying;

1.4 Sexual Bullying; and

1.5 Cyberbullying?

2. To what extent do the students report the bullying incidents in the following persons:

2.1 Friends;

2.2 Classmates/Schoolmates;

2.3 Neighbors;

2.3 Teachers;

2.4 Relatives; and

2.4 Parents?

3. To what extent do the students experience bullying from the following:

3.1 Friends; 
3.2 Classmates;

3.3 Neighbors;

3.4 Teachers;

3.5 Relatives; and

3.6 Parents?

4. What are the reactions of the students when they are bullied?

5. What are the effects of bullying?

\section{RESEARCH METHODS}

\section{Research Design}

This study used a descriptive research design wherein students' experiences, reactions and opinions will be gathered through well-structured survey questionnaires.

\section{Participants and/or Other Sources of Data and Instrumentation}

Students from all grade levels served as the respondents of this study. This study was conducted during the strict implementation of the COVID-19 protocols and lockdowns. Thus, purposive sampling technique was employed using snowball sampling technique. Online survey questionnaire was sent to the selected students via messenger. These students forwarded the online survey questionnaire to those students who they thought potential respondents of the study via messenger too. Snowball sampling is a nonprobability sampling technique where the selected potential respondents of the study recruited other potential respondents from their acquaintances. Thus, the sample group in this study grew like a rolling snowball.

A well-designed researcher-made survey questionnaire using 5-Point Likert Scale (5Always; 4-Often; 3-Sometimes; 2-Rarely; and 1-Never) was employed to determine the experiences, reactions and opinions of students on bullying (See the attached survey questionnaire). It consisted of 5 parts. Part I determined the extent of the experiences of students on bullying. Part II described the extent where the students reported the bullying incidents. Part III elicited the extent of the persons who might bully the students. Part IV determined the reactions of students when they were bullied. Part V described the opinions of students on the psychological effects bullying.

This research instrument had undergone validation and reliability tests to accurately elicit information needed in the study.

\section{Data Gathering Methods}

When the research instrument was found valid and reliable, the researcher sought the approval of the Schools Division Superintendent to conduct the study entitled 'Students' Experiences, Reactions and Opinions on Bullying at Esperanza National High School, Esperanza, Sultan Kudarat, Region XII, Philippines". Statistician was consulted for the computation of the number of samples.

Letter addressed to the School Administrator of Esperanza National High School was secured. Online orientation with the respondents was conducted before the distribution of the online survey questionnaires. The researchers explicitly explained the contents, purpose and significance of the study in order for the respondents to understand better what they answered, thus, giving more chances of accurate responses.

Class advisers were coordinated to help the researchers in getting very reliable sources of data and in the online distribution of the research instrument. Upon the possession of the 
data from online survey questionnaires, the researchers tallied the data for further analysis, interpretation and implication of the data.

\section{Data Analysis Plan}

To describe students' experiences, reactions and opinions on bullying they experience at school or at home, weighted mean was employed (for all research questions).

The following parameters was used to describe the experiences, reactions and opinions of students on bullying at school or at home:

$\begin{array}{ccc}\text { Scale } & \begin{array}{c}\text { Extent of Students' Experiences and } \\ \text { Reactions on Bullying }\end{array} & \begin{array}{c}\text { Extent of Students' } \\ \text { Opinions on the Effect of } \\ \text { Bullying }\end{array} \\ 4.20-5.00 & \text { Always } & \text { Very High } \\ 3.40-4.19 & \text { Often } & \text { High } \\ 2.60-3.19 & \text { Sometimes } & \text { Moderately High } \\ 1.80-2.59 & \text { Rarely } & \text { Low } \\ 1.00-1.79 & \text { Never } & \text { Very Low }\end{array}$

\section{RESULTS AND DISCUSSION}

\section{Bullying Incidence at Esperanza National High School}

Bullying is a repetition of irritable conduct displayed by someone using force or coercion to disturb others, particularly when this behavior is routinely manifested and involves onesided influence. Table 1 presents the extent of bullying incidence at Esperanza National High School.

Table 1. Extent of Bullying Experiences of Students

\begin{tabular}{llll}
\hline \hline \multicolumn{2}{l}{ Types of Bullying } & Mean & Description \\
\hline 1 & Physical Bullying & 1.74 & Never \\
2 & Verbal Bullying & 2.38 & Rarely \\
3 & Relational Bullying & 1.89 & Rarely \\
4 & Sexual Bullying & 1.55 & Never \\
5 & Cyber-Bullying & 1.42 & Never \\
\hline \multicolumn{2}{l}{ Overall Mean } & $\mathbf{1 . 8 0}$ & Rarely \\
\hline \hline
\end{tabular}

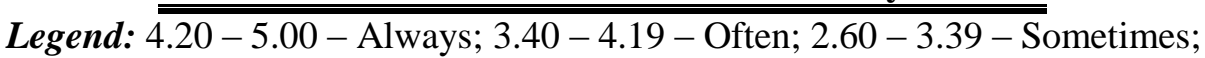
$1.80-2.59$ - Rarely; $1.00-1.79$ - Never

As shown, the overall mean of 1.80 described as "Rarely" means that there was only a minor incidence of bullying incidence at Esperanza National High School. Cyber-bullying and sexual bullying received the lowest means of 1.42 and 1.54, respectively. These two types of bullying did not ever happen in the school or at home as manifested by the verbal description of "Never". This signifies that both students and teachers were aware that any type of bullying doesn't have a place here at Esperanza National High School.

The above data confirm that Esperanza National High School has maintained a healthy school environment suited to the different types of learners. Al-Raqqad et al. (20217) stressed that a school with less incidence of bullying can really invite the learners to embrace the learning opportunities intended for their personal welfare and development. 


\section{Reporting of Bullying}

If a student is bullied and he has the courage to report the bullying incidence, bullying can be minimized. Table 2 presents the extent of reporting of incidence at Esperanza National High School.

Table 2. Extent of Reporting of Bullying Incidence

\begin{tabular}{clll}
\hline \hline \multicolumn{2}{l}{ Types of Persons } & Mean & Description \\
\hline 1 & Friends & 3.02 & Sometimes \\
2 & Classmates/Schoolmates & 2.56 & Rarely \\
3 & Neighbors & 1.94 & Rarely \\
4 & Teachers & 2.35 & Rarely \\
5 & Relatives & 2.57 & Rarely \\
6 & Parents & 2.81 & Sometimes \\
\hline Overall Mean & $\mathbf{2 . 5 4}$ & Rarely \\
Legend: $4.20-5.00-$ Always; 3.40-4.19-Often; $2.60-3.39-$ Sometimes; \\
\multicolumn{4}{r}{ 1.80-2.59- Rarely; $1.00-1.79-$ Never }
\end{tabular}

As shown, the overall mean of 2.54 described as "Rarely" shows that students rarely reported the minor incidence of bullying the experience from the school or at home. This finding is in consonance with the data in Table 1 that there was a rare incidence of bullying incidence they experienced. This means that the bullying they experienced was tolerable. In other words, bullying needs not to be reported since it doesn't really hurt them emotionally. That's why, they also rarely reported it to the concerned people.

The highest mean of 3.02 described as "Sometimes" indicates that students occasionally reported the incidence of bullying to their friends. They felt that the minor bullying they experienced should be reported to their friends rather than to their parents or teachers. The lowest mean of 1.94 described as "Rarely" denotes that students seldom reported the bullying in their neighbors.

It is, indeed, suggested that school should sustain the programs and activities in order to maintain the least extent of bullying at school.

\section{Bullying Experiences of Students}

Studies reveal that the lesser the extent of bullying in the school, the higher the motivation of the students to engage in the learning opportunities offered by the school. The extent of the bullying experiences of the students is presented in the following table.

Table 3. Extent of Bullying Experiences of Students from the Following Persons

\begin{tabular}{llll}
\hline \hline \multicolumn{1}{l}{ Types of Persons } & Mean & Description \\
\hline 1 & Friends & 2.36 & Rarely \\
2 & Classmates/Schoolmates & 2.51 & Rarely \\
3 & Neighbors & 2.03 & Rarely \\
4 & Teachers & 1.52 & Never \\
5 & Relatives & 2.24 & Rarely \\
6 & Parents & 1.73 & Never \\
\hline Overall Mean & $\mathbf{2 . 0 7}$ & Rarely \\
\hline \hline
\end{tabular}

Legend: 4.20 - 5.00 - Always; $3.40-4.19$ - Often; 2.60 - 3.39-Sometimes; $1.80-2.59$ - Rarely; $1.00-1.79-$ Never

As can be glimpsed from Table 3, the overall mean of 2.07 described as "Rarely" signifies that students very seldom experienced the bullying from the people they 
frequently engaged and communicated. In other words, these people were good influence in their day-to-day activities.

The highest mean of 2.36 still described as "Rarely" means that students experienced a bullying incidence from their friends in a least extent. In layman's language, they were compatible to mingle with their friends as they just only experienced a minor incidence of bullying from them and this is a normal situation for the teenagers to receive a rare bullying incidence from their friends.

This study suggests that students should choose their friends who can give them a good influence to grow as better persons. Hodges and Perry (1999) emphasized that students who are surrounded by good friends show positive attitudes towards studies.

\section{Reactions of Students when They are Bullied}

It is normal for the students to react if they are bullied. The extent of reactions of students when they are bullied is presented in Table 4.

Table 4. Extent of Reactions of Students When They are Bullied

\begin{tabular}{llll}
\hline \hline Types of Persons & Mean & Description \\
\hline 1 & $\begin{array}{l}\text { Physically walking away (Aalis sa lugar kung saan nagyayari } \\
\text { ang pananakot o panunukso) }\end{array}$ & Sometimes \\
\hline 2 & $\begin{array}{l}\text { Trying to act unaffected (Kunwaring di nasasaktan o } \\
\text { nasasaksihan ang pananakot o panunukso) }\end{array}$ & Sometimes \\
\hline 3 & $\begin{array}{l}\text { Not fighting the bully as this may escalate things and the } \\
\text { situation may become worse (Hindi na lalabanan ang nananakot } \\
\text { upang hindi na maglala ang sitwasyon) }\end{array}$ & Sometimes \\
\hline 4 & $\begin{array}{l}\text { Saying "No" in a loud voice (Pagsabi ng Malakas na "No" o } \\
\text { Tama Na) }\end{array}$ & Rarely \\
\hline 5 & Immediately retaliating (Agad na Paghihiganti) & Rarely \\
\hline 6 & $\begin{array}{l}\text { Standing and walking away that seems no bullying incident that } \\
\text { happens (Pagtayo at paglisan na kunwaring walang nangyaring } \\
\text { pananakot o pagpapahiya) }\end{array}$ & Sometimes \\
\hline 7 & $\begin{array}{l}\text { Not responding or replying to the bulling messages (Hindi } \\
\text { pagsagot sa pananakot o pagpapayahing text message) }\end{array}$ & Sometimes \\
\hline 8 & $\begin{array}{l}\text { Keeping evidence of cyber-bulling such as having a screen shot } \\
\text { of the bullying text message (Pagkuha ng ebidensya tulad ng } \\
\text { pag-screen shot ng mga pananakot na text message) }\end{array}$ & Sometimes \\
\hline 9 & $\begin{array}{l}\text { Reporting the bullying incident to the concerned authorities such } \\
\text { as teachers and policemen (Pagsumbong ng pananakot o } \\
\text { pagpapahiya sa mga guro o police) }\end{array}$ & Rarely \\
\hline 10 & $\begin{array}{l}\text { Reporting the bulling incidents to the parents (Pagsumbong ng } \\
\text { pananakot o pagpapahiya sa mga magulang) }\end{array}$ & Rarely \\
\hline Overall Mean & S.4. & Sometimes \\
\hline
\end{tabular}

\begin{tabular}{lll}
\hline Overall Mean & $\mathbf{2 . 7 1}$ & Sometimes \\
\hline
\end{tabular}

Legend: 4.20 - 5.00 - Always; 3.40 - 4.19 - Often; 2.60 - 3.39 - Sometimes; $1.80-2.59$ - Rarely; $1.00-1.79-$ Never

As shown, students' reactions if they are bullied were described as "Sometimes" as revealed by the overall mean of 2.71 . This indicates that they normally responded to the minor incidence of bullying they experienced from the school or at home. As a matter of fact, out of 10 statements, 6 of them received a verbal description of "Sometimes" and 4 statements garnered a description of "Rarely".

The highest mean of 3.34 described as "Sometimes" was received by the statement "Not fighting the bully as this may escalate things and the situation may become worse". 
This means that majority of the bullied students didn't fight back so that the bullying incidence will not be worsened. This is a very good reaction of the students who are bullied. However, they are advised to report the major bullying incidence. The indicator "Trying to act unaffected" received the second highest mean of 3.06 also described as "Sometimes". This means that students who are bullied by other students were pretentious as they were not affected. The lowest mean of 1.81 described as "Rarely" was received by the statement "Immediately retaliating". This indicates that students who are bullied didn't retaliate so that the issue will not become worse. The second to the lowest mean of 2.26 described as "Rarely" was received by the indicator "Reporting the bullying incident to the concerned authorities such as teachers and policemen". This means that students didn't report the bullying incidence to the concerned authorities since they believed that this bullying incidence was just only minor and tolerable.

The above finding indicates that majority of students just only ignored the bullying incidence since it was just only minor. Not fighting the bully and ignoring the minor bullying incidence they experienced was a good reaction of students so that bullies will not be tolerated to bully other students if they are always ignored.

\section{Effects of Bullying}

Studies indicate that bullied kids experience anxiety, fear, depression, and low self-esteem. They also may experience physical symptoms, and struggle academically. Targets of bullying also experience some unique consequences and negative feelings. Table 5 presents the extent of effects of bullying to the students.

Table 5. Extent of Effects of Bullying

\begin{tabular}{llll}
\hline \hline Effects of Bullying & Mean & Description \\
\hline 1 & Absenteeism & 2.33 & Rarely \\
2 & Traumatic Experience & 2.70 & Sometimes \\
3 & Suicidal Tendency & 2.18 & Rarely \\
4 & Lack of Self-Confidence & 3.35 & Sometimes \\
5 & Withdrawal from Family and & 2.50 & Rarely \\
& School Activities & & \\
6 & Wanting to be Left Alone & 3.10 & Sometimes \\
7 & Panic Attack & 2.59 & Rarely \\
8 & Not Being Able to Sleep & 2.79 & Sometimes \\
9 & Nightmares & 2.46 & Rarely \\
10 & Nervousness & 3.13 & Sometimes \\
11 & Depression & 2.78 & Sometimes \\
12 & Social Isolation & 2.60 & Sometimes \\
\hline Overall Mean & $\mathbf{2 . 7 1}$ & Sometimes \\
\hline \hline
\end{tabular}

Legend: 4.20 - 5.00 - Always; $3.40-4.19$ - Often; $2.60-3.39$ - Sometimes; $1.80-2.59$ - Rarely; $1.00-1.79-$ Never

As shown, the overall mean of 2.71 described as "Sometimes" indicates that students believed that bullying has a less extent of effect on their personal development. This finding is in consonance with the data in the previous tables that students experienced a less extent of bullying from the school and at home. In this case, they believed that this minor bullying they experienced had a less extent on them. This finding is confirmed by the 7 indicators described as "Sometimes" and 3 indicators construed as "Rarely". In other words, students who experienced less extent of bullying believe that it didn't really affect them as persons. 
The highest mean of 3.35 described as "Sometimes" was received by the indicator "Lack of Self-confidence". This means that students sometimes believed that if they are bullied, their self-confidence will become low. The indicator "Wanting to be Left Alone" got the second highest mean of 3.10 described as "Sometimes" also. This indicates that if they are bullied, they later wanted to be alone to think of the reasons why are bullied. However, this thought was seldom only as indicated by the verbal description of "Sometimes" only.

Previous tables confirmed that there was a minor incidence of bullying at Esperanza National High School. Students preferred to ignore the bullies so that the situation will not become worse. They opted to report the bullying incidence to their friends. They believed that if they are bullied, they become less confident.

\section{CONCLUSION}

Esperanza National High School has maintained a healthy school environment suited to the different types of learners since the bullying was less evident in the school. A school with less incidence of bullying can really invite the learners to embrace the learning opportunities intended for their personal welfare and development. If there is a rare occurrence of bullying, then students rarely report this incidence to the concerned people. Students very seldom experienced the bullying from the people they frequently engage and communicate. They normally responded to the minor incidence of bullying they experienced from the school or at home. They believed that bullying had a less extent of effect on their personal development.

\section{Recommendations}

Based from the findings and conclusions of the study, the following recommendations are herein formulated:

1. Esperanza National High School should sustain building a positive school environment and should maintain the zero tolerance of any bullying incidence in the school.

2. School should keep lines of communication and encourage students to report any form of bullying in the concerned authorities.

3. School should maximize the collaborative learning opportunities of the students so that they have the chance to have fun and meet other people with the same interests.

4. School should help the students to build their confidence and friendships that prevent them from any form of bullying.

5. Parents and teachers should help the students understand the bad effect of bullying. They should talk about what bullying is and how to stand up to it safely.

\section{REFERENCES}

Abdullah, S.N. (2016). The Effect of Student Absenteeism on Academic Performance: Basis for Developing Intervention Program. Action Research Funded by Basic Education Research Fund. Carpenter Hills, Koronadal City, Region XII

Al-Raqqad, H. A., Al-Bourni, E. S., Al-Talahin, F. M., \& Aranki, R. M. E. (2017). The Impact of Bullying on Students' Academic Achievement from Teachers Point of View. International Education Studies. 10(6), ISSN 1913-9020. Canadian Center of Science and Education

Beran, T. and Q. Li (2005). Cyber-Harassment: A New Method for an Old Behavior: Journal of Educational Computing Research, 32(3): 265-277 
Besag, V. (1989). Bullies and Victims in Schools, Milton Keynes, England: Open University Borg, M. G. (1999). The Extent and Nature of Bullying Among Primary and Secondary School Children, Educational Research, 41(2): 137-153

Clarke, E. A. and M. S. Kiselica (1997). A Systematic Counselling Approach to the Problem of Bullying, Elementary School Guidance and Couselling, 31, 310 - 315

Cross, D. (2008). Cyberbullying: International Comparisons, Implications and Recommendations, Wurzburg, Germany: Paper presented at the $20^{\text {th }}$ Biennial Meeting of the International Society for the Study of Behavioral Development

Hodges, E. and D. Perry (1999). Personal and Interpersonal Antecedents and Consequences of Victimization by Peers, Journal of Personality and Social Psychology

Li, Q. (2010). Cyber-bullying in High Schools: A Study of Students' Behaviors and Beliefs About This New Phenomenon, Journal of Aggression, Maltreatment and Trauma, Volume 19, 2010 Issue 4

Maliki, A. E., Asogwara, C. C., \& Ibu, J. E. (2009). Bullying and Its Effect on the Academic Performance of Secondary School Students in Nigeria. J Hum Ecol, 25(3), 209-213

\section{Appendices}

Survey Questionnaire On Students' Experiences, Reactions And Opinions On Bullying

Dear Student:

We are very happy to inform you that you are one of the respondents of our research entitled 'STUDENTS' EXPERIENCES, REACTIONS AND OPINIONS ON BULLYING AT ESPERANZA NATIONAL HIGH SCHOOL, ESPERANZA, SULTAN KUDARAT, REGION XII, PHILIPPINES”.

Thank you so much and more power to you!

RODALYN O. LAPADA

Lead Researcher

ELMER S. LAPADA

Co-Researcher

I. Use the 5-Point Likert Scale below together with its verbal description to accurately give your experiences regarding bullying incidents. Encircle the number that corresponds to your choice.

\begin{tabular}{|l|l|c|c|c|c|c|}
\hline \multicolumn{2}{|l|}{ Physical Bullying (Pisikal na Panankot) } & $\begin{array}{c}\text { Always } \\
(\mathbf{5})\end{array}$ & $\begin{array}{c}\text { Often } \\
(4)\end{array}$ & $\begin{array}{c}\text { Sometimes } \\
(3)\end{array}$ & $\begin{array}{c}\text { Rarely } \\
(\mathbf{2})\end{array}$ & $\begin{array}{c}\text { Never } \\
(1)\end{array}$ \\
\hline 1 & Kicking (Pagsipa) & 5 & 4 & 3 & 2 & 1 \\
\hline 2 & Hitting (Pagpalo) & 5 & 4 & 3 & 2 & 1 \\
\hline 3 & Punching (Pagsuntok) & 5 & 4 & 3 & 2 & 1 \\
\hline 4 & Slapping (Pagsampal) & 5 & 4 & 3 & 2 & 1 \\
\hline 5 & Shoving (Pagtulak) & 5 & 4 & 3 & 2 & 1 \\
\hline 6 & $\begin{array}{l}\text { Physical Assault (Pagsalakay o } \\
\text { Paglusob) }\end{array}$ & 5 & 4 & 3 & 2 & 1 \\
\hline 7 & Throwing of Object (Pagtapon ng & 5 & 4 & 3 & 2 & 1 \\
\hline
\end{tabular}




\begin{tabular}{|c|c|c|c|c|c|c|}
\hline \multirow{2}{*}{\multicolumn{2}{|c|}{\begin{tabular}{l|l} 
Bagay) \\
Verbal Bullying (Salitang Pananakot)
\end{tabular}}} & \multirow{3}{*}{$\begin{array}{c}\begin{array}{c}\text { Always } \\
(5)\end{array} \\
5\end{array}$} & \multirow[b]{2}{*}{$\begin{array}{l}\text { Often } \\
(4)\end{array}$} & \multirow[b]{2}{*}{$\begin{array}{l}\text { Sometimes } \\
(3)\end{array}$} & \multirow[b]{2}{*}{$\begin{array}{l}\text { Rarely } \\
(2)\end{array}$} & \multirow[b]{2}{*}{$\begin{array}{c}\text { Never } \\
(1)\end{array}$} \\
\hline & & & & & & \\
\hline 1 & Shouting (Pagsigaw) & & 4 & 3 & 2 & 1 \\
\hline 2 & $\begin{array}{l}\text { Harsh Statement (Masasakit } n a \\
\text { Salita) }\end{array}$ & 5 & 4 & 3 & 2 & 1 \\
\hline 3 & $\begin{array}{l}\text { Relentless Insult (Paulit-ulit Pag- } \\
\text { insulto) }\end{array}$ & 5 & 4 & 3 & 2 & 1 \\
\hline 4 & Belittling (Minamaliit) & 5 & 4 & 3 & 2 & 1 \\
\hline 5 & $\begin{array}{l}\text { Uttering Bad Words (Pagsasalita } \\
\text { ng Masasakit na Salita) }\end{array}$ & 5 & 4 & 3 & 2 & 1 \\
\hline 6 & Name-Calling (Pangungutya) & 5 & 4 & 3 & 2 & 1 \\
\hline 7 & $\begin{array}{l}\text { Verbal Harassment (Pamimilit } \\
\text { Gamit ang Matatapang na Salita) }\end{array}$ & 5 & 4 & 3 & 2 & 1 \\
\hline \multicolumn{2}{|c|}{$\begin{array}{l}\text { Relational Bullying (Pamiminsalang } \\
\text { Pananakot) }\end{array}$} & $\begin{array}{l}\text { Always } \\
(5)\end{array}$ & $\begin{array}{l}\text { Often } \\
(4)\end{array}$ & $\begin{array}{c}\text { Sometimes } \\
(3)\end{array}$ & $\begin{array}{l}\text { Rarely } \\
(2)\end{array}$ & $\begin{array}{l}\text { Never } \\
(1)\end{array}$ \\
\hline 1 & 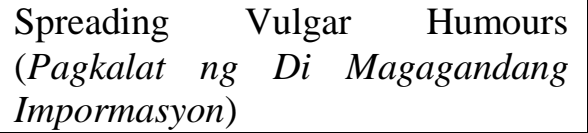 & 5 & 4 & 3 & 2 & 1 \\
\hline 2 & $\begin{array}{l}\text { Manipulating Situations (Paggawa } \\
\text { ng Di Makatotohanang Bagay) }\end{array}$ & 5 & 4 & 3 & 2 & 1 \\
\hline 3 & $\begin{array}{lcr}\text { Controlling } & \text { One } & \text { Person } \\
\text { (Ginagawang } & \text { Utus-utusan } & \text { ang } \\
\text { isang Tao) } & & \\
\end{array}$ & 5 & 4 & 3 & 2 & 1 \\
\hline 4 & $\begin{array}{l}\text { Damaging One's } \\
\text { (Maninirang Puri) }\end{array}$ & 5 & 4 & 3 & 2 & 1 \\
\hline 5 & $\begin{array}{l}\text { Making Fun of the Victim's } \\
\text { Appearance } \\
\text { Katatawanan ang Itsura ng Isang } \\
\text { Tao) }\end{array}$ & 5 & 4 & 3 & 2 & 1 \\
\hline 6 & $\begin{array}{l}\text { Revealing Secrets (Pagbulgar ng } \\
\text { Sekreto) }\end{array}$ & 5 & 4 & 3 & 2 & 1 \\
\hline 7 & Backstabbing (Panlilibak) & 5 & 4 & 3 & 2 & 1 \\
\hline \multicolumn{2}{|c|}{$\begin{array}{l}\text { Sexual Bullying (Pambabastos } \quad \text { o } \\
\text { Panliligalig) }\end{array}$} & $\begin{array}{l}\text { Always } \\
(5)\end{array}$ & $\begin{array}{l}\text { Often } \\
(4)\end{array}$ & $\begin{array}{c}\text { Sometimes } \\
(3)\end{array}$ & $\begin{array}{l}\text { Rarely } \\
(2)\end{array}$ & $\begin{array}{c}\text { Never } \\
(1)\end{array}$ \\
\hline 1 & $\begin{array}{l}\text { Crude Comments (Masasamang } \\
\text { Komento) }\end{array}$ & 5 & 4 & 3 & 2 & 1 \\
\hline 2 & $\begin{array}{l}\text { Vulgar Gestures (Pagkilos } n g \quad \mathrm{Di} \\
\text { Kanais-nais) }\end{array}$ & 5 & 4 & 3 & 2 & 1 \\
\hline 3 & $\begin{array}{l}\text { Uninvited Touching (Paghawak ng } \\
\text { Masseselang Bahagi ng Katawan) }\end{array}$ & 5 & 4 & 3 & 2 & 1 \\
\hline 4 & $\begin{array}{l}\text { Sexual Propositioning (Pagyaya } n g \\
\text { Pagtatalik) }\end{array}$ & 5 & 4 & 3 & 2 & 1 \\
\hline 5 & $\begin{array}{l}\text { Forcing Someone to Watch } \\
\text { Pornographic Materials (Pamimilit } \\
\text { na Manood ng Maseselang } \\
\text { Panoorin) }\end{array}$ & 5 & 4 & 3 & 2 & 1 \\
\hline \multicolumn{2}{|c|}{$\begin{array}{l}\text { Cyber Bullying (Panunukso, Panlalait, } \\
\text { Pananakot o Pang-aasar Gamit ang } \\
\text { Social Networking Services) }\end{array}$} & $\begin{array}{l}\text { Always } \\
\text { (5) }\end{array}$ & $\begin{array}{l}\text { Often } \\
(4)\end{array}$ & $\begin{array}{l}\text { Sometimes } \\
\text { (3) }\end{array}$ & $\begin{array}{l}\text { Rarely } \\
(2)\end{array}$ & $\begin{array}{l}\text { Never } \\
\text { (1) }\end{array}$ \\
\hline 1 & 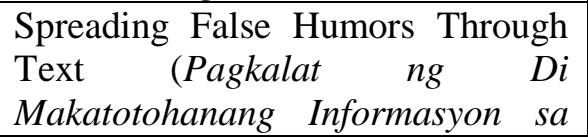 & 5 & 4 & 3 & 2 & 1 \\
\hline
\end{tabular}




\begin{tabular}{|l|l|c|c|c|c|c|}
\hline & Pamamagitan ng Text) & & & & & \\
\hline 2 & $\begin{array}{l}\text { Posting Humors in the Social } \\
\text { Media (Pagkalat ng Nakakahiyang } \\
\text { Bagay Laban sa Kapwa sa Social } \\
\text { Media) }\end{array}$ & 5 & 4 & 3 & 2 & 1 \\
\hline 3 & $\begin{array}{l}\text { Uploading Videos that can Damage } \\
\text { One's Reputation (Pag-upload ng } \\
\text { Maseselang Panoorin na } \\
\text { Nakakasira sa Isang Tao) }\end{array}$ & 5 & 4 & 3 & 2 & 1 \\
\hline 4 & $\begin{array}{l}\text { Blackmail (Pananakot Gamit ang } \\
\text { Cell Phone o Social Media) }\end{array}$ & 5 & 4 & 3 & 2 & 1 \\
\hline
\end{tabular}

II. Where do you prefer to report the bullying incidents? Please give your perception in the space provided for each type of persons you intend to report the bullying incidents at school or at home. Use the 5-Point Likert Scale for your answer: 5 - Always, 4 - Often, 3 - Sometimes, 2 - Rarely and 1 - Never.

\begin{tabular}{|l|l|}
\hline Friends & \\
\hline Classmates/Schoolmates & \\
\hline Neighbors & \\
\hline Teachers & \\
\hline Relatives & \\
\hline Parents & \\
\hline
\end{tabular}

III. Who bully you in the school or home? Please give your perception in the space provided for each type of persons who bully you school or at home. Use the 5-Point Likert Scale for your answer: 5 - Always, 4 - Often, 3 - Sometimes, 2 - Rarely and 1 - Never.

\begin{tabular}{|l|l|}
\hline Friends & \\
\hline Classmates/Schoolmates & \\
\hline Neighbors & \\
\hline Teachers & \\
\hline Relatives & \\
\hline Parents & \\
\hline
\end{tabular}

IV. The following survey questionnaire will determine the level of your reaction when you are bullied. Please encircle the number of your choice.

\begin{tabular}{|l|l|c|c|c|c|c|}
\hline No. & Reactions on bullying incidents & $\begin{array}{c}\text { Always } \\
\text { (5) }\end{array}$ & $\begin{array}{c}\text { Often } \\
\text { (4) }\end{array}$ & $\begin{array}{c}\text { Sometimes } \\
\text { (3) }\end{array}$ & $\begin{array}{c}\text { Rarely } \\
\text { (2) }\end{array}$ & $\begin{array}{c}\text { Never } \\
\text { (1) }\end{array}$ \\
\hline 1 & $\begin{array}{l}\text { Physically walking away (Aalis sa } \\
\text { lugar kung saan nagyayari ang } \\
\text { pananakot o panunukso) }\end{array}$ & 5 & 4 & 3 & 2 & 1 \\
\hline 2 & $\begin{array}{l}\text { Trying to act unaffected } \\
\text { (Kunwaring di nasasaktan o } \\
\text { nasasaksihan ang pananakot o } \\
\text { panunukso) }\end{array}$ & 5 & 4 & 3 & 2 & 1 \\
\hline 3 & $\begin{array}{l}\text { Not fighting the bully as this may } \\
\text { escalate things and the situation } \\
\text { may become worse (Hindi na } \\
\text { lalabanan ang nananakot upang } \\
\text { hindi na maglala ang sitwasyon) }\end{array}$ & 5 & 4 & 3 & 2 & 1 \\
\hline
\end{tabular}




\begin{tabular}{|l|l|l|l|l|l|l|}
\hline 4 & $\begin{array}{l}\text { Saying "No" in a loud voice } \\
\text { (Pagsabi ng Malakas na "No" o } \\
\text { Tama Na) }\end{array}$ & 5 & 4 & 3 & 2 & 1 \\
\hline 5 & $\begin{array}{l}\text { Immediately retaliating (Agad na } \\
\text { Paghihiganti) }\end{array}$ & 5 & 4 & 3 & 2 & 1 \\
\hline 6 & $\begin{array}{l}\text { Standing and walking away that } \\
\text { seems no bullying incident that } \\
\text { happens (Pagtayo at paglisan na } \\
\text { kunwaring walang nangyaring } \\
\text { pananakoto pagpapahiya) }\end{array}$ & 5 & 4 & 3 & 2 & 1 \\
\hline 7 & $\begin{array}{l}\text { Not responding or replying to the } \\
\text { bulling messages (Hindi pagsagot } \\
\text { sa pananakot o pagpapayahing } \\
\text { text message) }\end{array}$ & 5 & 4 & 3 & 2 & 1 \\
\hline 8 & $\begin{array}{l}\text { Keeping evidence of cyber-bulling } \\
\text { such as having a screen shots of } \\
\text { the bullying text message } \\
\text { (Pagkuha ng ebidensya tulad ng } \\
\text { pag-screen shot ng mga pananakot } \\
\text { na text message) }\end{array}$ & 5 & 4 & 3 & 2 & 1 \\
\hline 9 & $\begin{array}{l}\text { Reporting the bullying incident to } \\
\text { the concerned authorities such as } \\
\text { teachers and policemen } \\
\text { (Pagsumbong ng pananakot o } \\
\text { pagpapahiya sa mga guro o } \\
\text { police) }\end{array}$ & 5 & 4 & 3 & 2 & 1 \\
\hline $\begin{array}{l}\text { Reporting the bulling incidents to } \\
\text { the parents (Pagsumbong ng } \\
\text { pananakot o pagpapahiya sa mga } \\
\text { magulang) }\end{array}$ & 5 & 4 & 3 & 2 & 1 \\
\hline
\end{tabular}

$\mathrm{V}$. The following survey questionnaire will determine your opinions about the effect of bullying. Please encircle the number of your choice.

\begin{tabular}{|l|l|c|c|c|c|c|}
\hline No. & \multicolumn{1}{|c|}{ Effect of Bullying } & $\begin{array}{c}\text { Always } \\
\mathbf{( 5 )}\end{array}$ & $\begin{array}{c}\text { Often } \\
\mathbf{( 4 )}\end{array}$ & $\begin{array}{c}\text { Sometimes } \\
\mathbf{( 3 )}\end{array}$ & $\begin{array}{c}\text { Rare } \\
\mathbf{( 2 )}\end{array}$ & $\begin{array}{c}\text { Never } \\
(\mathbf{1})\end{array}$ \\
\hline 1 & Absenteeism & 5 & 4 & 3 & 2 & 1 \\
\hline 2 & Traumatic Experience & 5 & 4 & 3 & 2 & 1 \\
\hline 3 & Suicidal Tendency & 5 & 4 & 3 & 2 & 1 \\
\hline 4 & Lack of Self-Confidence & 5 & 4 & 3 & 2 & 1 \\
\hline 5 & $\begin{array}{l}\text { Withdrawal from Family and } \\
\text { School Activities }\end{array}$ & 5 & 4 & 3 & 2 & 1 \\
\hline 6 & Wanting to be Left Alone & 5 & 4 & 3 & 2 & 1 \\
\hline 7 & Panic Attack & 5 & 4 & 3 & 2 & 1 \\
\hline 8 & Not Being Able to Sleep & 5 & 4 & 3 & 2 & 1 \\
\hline 9 & Nightmares & 5 & 4 & 3 & 2 & 1 \\
\hline 10 & Nervousness & 5 & 4 & 3 & 2 & 1 \\
\hline 11 & Depression & 5 & 4 & 3 & 2 & 1 \\
\hline 12 & Social Isolation & 5 & 4 & 3 & 2 & 1 \\
\hline
\end{tabular}

